Skopje vesnapetreska@hotmail.com

\title{
Љубов, сексуалност и казна во македонската традиционална култура
}

Abstract: Petreska Vesna, Ljubov, seksualnost i kazna vo makedonskata tradicionalna kultura (Love, Sexuality and Punishment in Macedonian Traditional Culture). "Poznańskie Studia Slawistyczne" 9. Publishing House of the Poznań Society for the Advancement of the Arts and Sciences, pp. 353-368. ISSN 2084-3011.

The love, sexuality and the punishment in the Macedonian traditional culture is considered on the basic of the ethnological-anthropological analyze. The analyze is based on the oral stories, ritual practices and oral poetry, which I take as means of communication. The love and the love emotions were in accordance with social and cultural criteria of the community in which occurred. This means that the love emotions, primarily the sexual emotions, had to be controlled, or to be shown as much as the traditional culture allowed. In general this was meant for the women and the maidens, ,a woman's chastity", that implies the women's purity and innocence. Otherwise the punishment commences. The betrayed young woman that has totally surrendered to the love emotions or the unjustly accused wife of infidelity is reaching towards the curse in order to satisfy the justice.

KEYwords: love; sexuality; punishment; Macedonian traditional culture; emotions; chastity; curse

Имајќи во обзир дека една од најголемите вредности во традиционалните култури било засновањето брак, којшто во голем број случаи се заклучувал со меѓусебно договарање на двете семејни заедници, со мало внимание на желбата на младите, тогаш е разбирливо, младите да извршуваат серија активности насочени кон негова реализација со саканиот/саканата. Активностите насочени кон „успешна реализација на бракот" со саканиот/саканата, главно биле со вешто посредување од страна на мајката (овде, пред сѐ, се мисли на убедувањето на таткото од страна на мајката, да го дадат нивното дете за саканиот или саканата), но и со магиските постапки кои влегуваат во доменот на „љубовната магија”, кои главно биле извршувани од девојките, 
поради желбата да се биде со саканиот. Со самото ова, го допираме и прашањето на љубовта и поврзаните со неа емоции.

Љубовта, сексуалноста, и поврзаните со неа емоции, како и телото, телесните функции, телесните излачувања, не биле во голем обем предмет на етнолошките и фолклористичките истражувања. Антрополошките, етнолошките и фолклористичките истражувања во XIX, како и во првите децении на XX век, биле во духот на платонската филозофија и христијанското наследство и го одвојуваат духовното и телесното, давајќи приоритет на „духовните” аспекти на културата во своите истражувања, па така и љубовта повеќе ја поимале како платонска. Објавувањето на фолклорни материјали со еротска насоченост, во тој временски период се сметало за недолично, а творбите со еротска проблематика се објавувале не според својата изворна форма, туку во адаптирана и изменета форма. Friedrich Solomon Kraus, автор на најобемното дело од областа на традиционалната еротика, „Kryptadia” (1883-1911) и „Anthropohyteia” (1904-1913), бил принуден да се помири со констатацијата дека има недостиг на финансиска подржка поради официјално неодобрување и вознемирување (Пиличкова 2009: 9). И истражувачите после него, во најголем дел сакале да останат анонимни, поради ризикот да бидат професионално дискредитирани поради погрешното интерпретирање на нивниите научни залагања. Дури и во С. Томпсоновиот „Motif Index of Folk Literature”, само се констатира дека во народната традиција постојат и народни творби со еротски елементи, како што и во Анти Арне и Стит Томпсоновиот Индекс „ТTe Types of the Folktale”, повеќето типови еротски умотворби се несоодветно одредени и наративната структура на приказните со еротски елементи во овој Индекс е одбележана само со издвојување со посебна бројка, покрај која стои и нотацијата „Obscene” (непристојно) која упатува на тематиката во сижетот од конкретна творба (Пиличкова 2009: 9-10). Во втората половина на XX век почнува да се има потолерантен однос кон истражувачите на народното творештво со еротска тематика, и во оваа смисла треба да се посочи специјалниот број посветен на еротските народни умотворби од списанието „Journal of American Folklore” (1962), Франк Хофман (Hofman 1973), и др. Состојбата е слична и во јужнословенските простори. Запишаните еротски песни од Вук С. Караџиќ, се издадени од страна на САНУ во Белград во 1974 година, каде на корицата со полуцрни 
букви стои „Само за научну употребу” (Караџић 1974)ํ. Во последните децении на XX век почнува поотворено да се истражува и еротскиот фолклор (Пенушлиски 1974; 1989; Величковски 1989; Ристески 1994; Топорков 1995; 1996; Grzybeg 1999; Ajdačić 2000; Gura 2005; Мартиноска 2007; Пиличкова 2009 и др.). Во трудот, етнолошко-антрополошката анализа на љубовта, сексуалноста и казната е правена на основа на усни кажувања, обредни практики и на усното поетско творештво кои ги земам како средства за комуникација.

Теориските размислувања за љубовта се движат во различни правци. Фројдовата психоанализа истакнува дека љубовта е темел на културата, иако нивниот однос е во постојан судир бидејќи љубовта се спротивставува на интересите на културата, а културата ја загрозува љубовта со ограничувањата (Freud 1988: 39). Културната задача според Фројд е да се сублимира нагонската сексуалност пренесувајќи ја во пожелен облик на меѓучовечки емотивни интеракции, да се трансформира човековата либидност во прифатлив културен код (Škokić 2011: 15). Понатамошните истражувања на неговите наследници (Lou Andreas-Salomé) paбoтејќи на меѓусебниот однос на заљубените, истакнуваат дека културата во ваквата концепција на љубовта ќе биде повеќе фактор кој ја одобрува љубовта, отколку што ја спречува (Škokić 2011: 17-18).

Културо-антрополошките теории и социолошките истражувања посебно конструктивистичкиот пристап истакнуваат на меѓусебното влијание на луѓето и општеството, процес во кој „луѓето го произведуваат општеството”, кое пак истовремено „ги произведува луѓето”, во кое се создаваат специфични типизации на односи. Според ова сексуалноста, а тука би ја додала и љубовта не можат да се толкуваат како унииверзален феномен, било да се работи за историски времиња или културни простори, односно „сексуалноста е креирана од културата”, а културата е таа која ги определува поедините однесувања и врски како сексуални, како што и ги учи припадниците на своето општество што е тоа што е сексуално (Škokić 2011: 42-43).

При зборувањето за љубовта, неизоставно е и прашањето за сексуалноста. Мишел Фуко (Michel Focault) зборува за дискурсите за

${ }^{1}$ Додека другите четири томови од истава едиција се со тираж од 30.000 примероци, овој том е со вкупен тираж од 500 примероци. 
сексуалност, кои ја произвеле сексуалноста каква што ја познаваме од XIX век. Всушност станува збор за производство на сексуалноста и тоа со дискурсот на моќта кој присвојува определен начин на говор, истовремено ја конструира праксата, но и „обезбедува” сопствено траење и конструира специфично значење за сексуалноста (Foucault 1978: 8-37). Всушност Фуковата теза е дека измислувањето на сексуалноста е дел од процесот нужен за создавање и јакнење на модерните општествени институции, а со тоа и за општествена контрола на сексуалноста (Foucault 1978) и дисциплинирање на нашите тела, а тука е и казната (Фуко 2004).

Во врска со љубовта, заслужува да се спомене и концептот на романтична љубов, кој помасовно се појавува во XVII век, и според Лумановата теза (Niklas Luhmann) за истовремено настанување на идејата за индивидуалноста, која во „временска и социјална димензија” се обликува во XVIII век, може да упатува на заклучок дека романтичната љубов каква што денес ја познаваме е прозивод на модернистичкот концепт на индивидуалитет. Некои (Eva Illouz) ќе ја прогласат за производ на капитализмот, плодно место за социјални разлики и културни конструкции кои одговараат на развојот на капиталистичката и економската политика, додека пак Антони Гиденс (Anthony Giddens), романтичната љубов ја прогласува подемократска и еманципациска, за разлика од страсната љубов, која изразува општа поврзаност на љубовта и сексот. Оваа Гиденсова интерпретација на модернизмот и романтичната љубов е критикувана од Џек Гуди (Jack Goody), кој алудира дека романтичната љубов не е ослободена од сексуалноста, таа вклучува сексуален однос, поврзана е со интимноста и присутна во разни краеви на светот, што јасно става до знаење дека не е специфично европска. Ова според Џ. Гуди значи дека не може да се раздвојува страсната (amour passion) и романтичната љубов и дека не е можно првата да се прогласи за универзална, а втората како „културно посебна”, затоа што тоа би значело дека ако е „романтичната љубов модерна, модернизмот е европски, па затоа и љубовта е европска". Со Гудиевата критика се сложуваат и други антрополози кои тврдат дека во Гиденсовите и слични објаснувања станува збор за етноцентрично поимање на човечките емоции според кои на западњаците им припаѓа љубовта и романтиката, а на Другите желбата и копнежот (Škokić 2011: 140, 144-146). 
Тргнувајќи од фактот дека една од најголемите вредности во традиционалните култури било склучувањето брак, тогаш е јасно дека овој вредносен модел ќе се настојува да им се всади на децата уште во процесот на социјализација. Во текот на процесот на социјализација децата во некоја мера и се приготвуваат на љубов. Македонските материјали, особено оние од почетокот на векот (Целакоски 1984: 213-241; Хаџи-Васиљевић 1927: 48; Икономов 1988: 151-166; Ристески 1961-1962; Петреска 2002), но и материјалите од други јужнословенски простори ${ }^{2}$, како што исто било и во предмодерна Европа покажуваат дека стапувањето во брак било можно само со договарање на претставници на двете семејни заедници, без да се води многу сметка за желбата на младите. Ако прифатиме дека она што го разликува бракот на современото општество од бракот на традиционалното општество е регулацијата на љубовта и дека некогаш љубовта морала да се контролира пред да се појави, па затоа и не чуди што до љубов доагало дури во брак (Škokić 2011: 158), тогаш можеме да зборуваме дека неизоставни биле младешките симпатии.

Овие емотивни аспекти кон симпатијата, младите настојувале да ги „решат” во своја корист со посредство на мајката или пак со активностите од љубовната магија. Идеалниот модел на однесување на младите во македонската традиционална култура подразбирал изборот на брачниот другар да биде во согласност со оној на родителите, а љубовта и особено емоциите морале вешто да се контролираат или пак да се покажат во границите на „дозволеното”. Во оваа смисла, ако зборуваме за романтична љубов, таа се изразувала платонски и во согласност со христијанската доктрина. Скришното погледнување

2 За свадбените обичаи, обреди и верувања на јужнословенските и балканските простори, има обилна етнолошка и фолклористичка литература. Да се види на пр. „Македонски фолклор” бр. 9-10, год. V, 1972; материјали од II Меѓународен симпозиум за балкански фолклор, 1971 Охрид, тема: Свадбените обреди, игри и песни кај народите на Балканот, стр. 9-210; „Македонски фолклор” бр. 29-30, год. 15 1982; материјали од VII Меѓународен симпозиум за балкански фолклор, 1981 Охрид, тема: Семејните обреди (обичаи), игри и песни на балканските народи, стр. 13-130; Zbornik XII Kongresa jugoslovenskih folkloristov, 1965 Celje, 1968 Ljubljana, тема: Arhaični elementi v svatbenih običajih, стр. 133-277; XXVIII Конгрес Савеза удружења фолклориста Југославије. Зборник радова, 1981 Сутоморе, тема: Свадба некад и данас, стр. 105-184; Кајмаковић, Костић 1961: 153-176. 
на двајца млади било знак дека меѓу нив постои нешто, испраќањето китка цвеќе или плод од некое овошје, во најголем број случаи јаболко, или пак останувањето кратко време насамо да разговараат и да си ги кажат своите „мераци”, се границите што заедницата ги дозволува на индивидуите во романтичната љубов. Ова особено се однесувало кон девојките, бидејќи „неконтролираните емоции” имале тешки последици во понатамошниот брачен живот. Овде се мисли на женската „чесност”, која во прв ред се однесувала на нејзината сексуална чесност. Затоа, и свадбените обреди „сведување на младите” и „прославување чесноста на невестата” или познат уште како блага ракија, заземале едно од централните, ако не и клучни места во целокупниот свадбен обреден комплекс (Петреска 2002: 490; Петреска 2008: 165). Што се однесува до чесноста, пред сѐ сексуалната, скорешните теренски истражувања со постара популација во поглед на родовите ги следат традиционалните правила, за разлика од младата која не ги следи нив (Петреска 2008: 164). Во прилог на ова можеме да ги споменеме и пословиците кои се со негативна конотација кон жените: „Мажот за жената никогаш не научува нешто, а ако научи, ќе го научи кога ќе биде доцна”, „Мажот цел век да куќи, жена за час раскуќува”, но постојат и такви кои не се со негативна конотација: „Мажот гради куќа, а жената дом”, „Умните мажи си ги почитуваат жените” (Величковски 2009: 116, 210). Иако не се одобрувала многу машката нечесност, сепак кон неа не се однесуваат со строга осуда, дури понекогаш во машкиот свет тие мажи се гледале како „способни”.

Истражувањата вршени при проучување на традиционалната свадба ми покажуваат неколку начини на избор на брачен партнер. Едниот е младите да ги почитуваат нормите на патријархалното воспитување, па во согласност со тоа, изборот на брачниот другар да биде во согласност со оној на родителите, без да се води сметка за сопствените желби. Во овој случај можеме да зборуваме за регулација на љубовта, карактеристична за традиционалните општества, дека љубовта морала да се контролира пред да се појави, па затоа и не чуди што до љубов доаѓало дури во брак (Škokić 2011: 158). Овде доаѓa до јасно потиснување на љубовните емоции, за да се биде во согласност со барањата на семејството, општествената заедница, односно да се биде во согласност со утврдените морални кодекси. Теренските материјали 
за ваков избор на брачен партнер покажуваат како примери кога понатамошниот брачен живот на младите се движи по еден нормален колосек, така и примери кога мажената жена не била задоволна во бракот со изборот на нејзините родители. Во песните можеме да најдеме примери на незадоволство на девојката, бидејќи е омажена за оној што не го сакала, најчесто тој е мало дете или пак стар.

Канам те, ќерко, канам те, / Канам те, Руно поканвам, / У мајка дојди на гости, / Заедно со стопана ти; / Вечер чиниме првиче, / За љубов, ќерко зетоа. / Како да дојдам, мајче ле, / Срцево ми го изгоре! / Зетот је мошне малечок, / Ах, ти ме зеде на душа...! (Миладиновци 1962: 403; Шапкарев 1976: 330-331, 355-356).

... - Ослепела, мајко ле, / оти ме мене продаде, / преку пусти Вардара? / Момче старо је харо, / рака имат, как' дрво, / бела брада боцкојт!! (Шапкарев 1976: 370, песна бр. 759) $)^{3}$.

Вториот начин е оној кога желбата на родителите се поклопува со оној на младите, што значи дека процесот на социјализација е добро поминат, бидејќи изборот на младите е во согласност со оној на родителите. Но, не секогаш љубовта можела да се контролира пред да се појави, или да се биде во согласност со желбата на родителите. Кога таа ќе се почувствувала, кога лично ќе се доживее, дури тогаш може да се зборува како се однесуваме кон правилата, нормите и обичаите кои ни се понудени или наметнати. Покрај погоре споменатите начини е изборот младите да си го направат самите, што значи дека меѓу младите љубовните емоции веќе постоеле. Во ваков случај многу често девојката одела за саканото момче. Овој тип е познат како бегалка. Девојките што не се покориле на волјата на родителите, и отишле за саканиот морале на своја кожа да го почувствуваат и лутењето од страна на нивните родители. Но, најчесто нивното лутење завршувало со празникот Прочка ${ }^{4}$, кога девојката заедно со момчето оделе кај нејзините родители со барање да им простат. Ретки се примерите, кога родителите, особено таткото, не сакале да се смират со нивната ќерка.

${ }^{3}$ Со слични мотиви кај балканските Словени, Krstić 1984: 245.

${ }^{4}$ Според народниот календар, седмата недела пред Велигден се празнува празникот Прочка. Календарски може да се падне од 14 февруари до 20 март по н.к. Бидејќи во овој ден се прави и покладна вечера, по која започнува седумнеделниот пост, овој празник кај народот е познат и како Сирни или Проштени поклади, а под влијание на црковниот календар и како Велики Поклади (Малинов, 2006: 130). 
Лутината, таткото ја изразувал во вид на клетва, а во традиционалната култура, особено се сметала за тешка татковата клетва, веројатно тргнувајќи од народното дека клетвата е во домен на жената. Во еден пример таткото ја колнел ќерката „дете да не фати во рака”, по што морала да интервенира мајката, барајќи од таткото да ги повлече овие зборови, бидејќи и претходната ќерка отишла бегалка, била проколната и клетвата се исполнила 5 .

Љубовните емоции понекогаш знаеле да избијат во неочекуван момент, кога еден од младите требало да стапи во брак. Како еден од поретките примери е од Кривопаланчеко, с. Дурачка Река, кога таткото сакал да ја омажи ќерката за некој богат. На самата свадба, девојката стоела пред олтарот на венчавање, но при самиот чин на венчавање го здогледува нејзиниот сакан, и таа се омажила за него. Интересно е што мислењата на селската заедница биле на страната на девојката, т.е. на страната на љубовта, а не ја одобрувале постапката на таткото ${ }^{6}$. Дека селската заедница знае да биде на страната на љубовта, т.е. на „дозволените љубовни емоции”, се и кажувањата дека еден од најголемите гревови е растурање на свадба, што многу често се споредува и како растурање на манастир, а во согласност со сторениот грев и казните (било да се натприродни или човечки) се големи, како и верувањата дека луѓе што „растуриле” работа за свадба ги чекаат маки на „оној” свет (Петреска 2012: 138).

Во усното народно творештво познати се приказни од типот дека гревовите и на најголемите убијци ке бидат простени, доколку успеат да попречат некого во расипувањето работа за свадба 7 . Во овој ред можеме да ги споменеме и љубовните емоции на изневерениот. Во

5 АИФ, м.л. бр. 3990, инф. М.Ч.Б., р. 1936 г. во с. Богданци - Гевгелиско Снимила: Весна Петреска во с. Ѓавато - Гевгелиско во 2002 г.

${ }^{6}$ АИФ, м.л. бр. 3752, инф. Р. М. р. 1940 г. во с. Дурачка река - Кривопаланечко. Снимила: Јелена Цветановска во с. Станци- Кривопаланечко.

7 Попвасилева 1996: 293. Приказната припаѓa кон типот АT 756 C I II III IV. Слична варијанта: Тановић 1927: 146-147. Расипување работа за свадба како најголем грев наогаме и во поетското творештво на некои други јужнословенски народи. Во една српска песна најголеми гревови забележана од Вук С. Караџиќ, се повикува Никола да оди во гора да прави кораби за пренос на душите од овој на оној свет. Никола направил кораби, но, само три души не можеле да се пренесат од овој на оној свет: ,jedna duša griješna:/ kuma na sud vodila:/ druga duša griješna:/ s komšijom se mrazila:/ treća duša najgri- 
вакви случаи изневерените љубовни емоции поминуваат и во емоции на лутина, а личноста во ваква емотивна состојба многу често помошта ја бара во натприродното со помош на клетвата. Случувањето на некоја несреќа на оној за кого била наменета клетвата, што во народното гледање се поимало како казна бил „сигурниот знак” дека таа се исполнила. Во еден пример од Кривопланечко, една девојка не го исполнила ветувањето да оди бегалка, а во договореното време таа го испратила нејзинот брат облечен како девојка. Братот на девојката кога се сретнал со момчето не дозволил девојката да оди за момчето. Но, нејзината постапка не може да остане неказнета. Мајката на момчето кога го дознала ова, излегла надвор, се прекрстила и рекла „да не се с'стави со мушко”. Ова значи дека клетвата е искажана јавно. Најдобар доказ за верувањето во моќта на клетвата е дека девојката не се омажила, а таа самата признала дека е проколната од мајката на момчето, односно бабата на информаторката: „таа и ден д’нска не е омажена. Цело село знае дека е тој клетва од баба ми. Ја сакале на многу места, но, таа не се омажила"8.

Без разлика дали девојката стапила во брак во согласност со желбата на родителите, со нејзина желба која не е во спротивност со онаа на родителите, или пак е отидена бегалка за саканото момче, сепак љубовните емоции кои веќе постоеле, морале да се контролираат, или пак да се покажат онолку колку што било дозволено во традиционалната култура. Станува збор дека љубовните емоции биле во сферата на духовното, додека телесните емоции особено девојката морала вешто да ги прикрива или да ги покаже во најмала мера. Во спротивен случај настапува и казната. Во прилог на ова е едно кажување на една информаторка за сопствената свадба. Ја земале една недела порано пред свадбата. Ја делела истата постела со нејзинот иден маж, но таа не сакала да стапи во сексуални односи пред официјалнот ден на свадбата:

Ќе чекаме свадбата. Он ми вика, ако има нешто јас ќе те скрија, еле си те сакам вика. Викам јас неќу да ме крие никој, ја сам се сама скрила. Можда нема чејс да

ješnija:/ djevojku je skudila” (Mencej 1997: 76-77 цитирано според: V.S. Karadžić, Najveći grijesi, 1969/1:101-102, [t. 209]).

8 АИФ м.л. 3754. Инф. Н. К. р. 1960 во с. Станци и Д. Ј.p. 1961. Снимила: Ј. Цветановска во с. Станци - Кривопаланечко во 2000 год. 
донеса, намештај, ама това што си го имам това на тебе дар ќе је. Това што го имам на тебе ќе е, а ти не ме закачај викам, зема да плачам... Можда немам друго, ама това што си го носам 9 .

Нејзината чесност била прославена со обредноста по тој повод - месење погача, благо, блага ракија, колење кокошки, и одење кај нејзините родители ${ }^{10}$. Во словенските култури сексуалниот однос бил симбол на брачна заедница, од каде што и првиот сексуален однос и дефлорацијата се сметале задолжителни за првата брачна ноќ. Семантиката за заедништво е рефлектирана во именувањето на обредната практика при „првиот” сексуален однос: мак. „сведување на младите, одење заедно во одаја”, (м.заб.) буг. „сводене, свеждане, срп. свођење, слагање; рус. вступить в связь, иметь близость”, пол. „spółkować” (Gura 2005: 146), како што и самата дефлорација, белегот на кошулата на невестата се именува со цвеќе, ружа (Петреска 2002: 305).

Како една од поблагите казни на ниво на селска заедница при „неконтролираните емоции” било озборувањето, кое се дефинира како тип на секојдневна комуникација кое вклучува ширење на информации за трети лица, без нивно знаење, одобрување или консултирање и без нивно присуство. Може да се смета како можна рамнотежа во заемното дејство меѓу културата и поединецот, и озборувањето е едно од средствата преку кое културата во извесна мера го регулира однесувањето на поединците на кои сепак им останува правото на избор, со што се потврдува нивниот статус на активни учесници во рамките на сопствената култура. Тоа во исто време ги рефлектира можностите на дејствувањето на поединците, од една страна, и ограничувањата кои ги наметнува заедницата од друга страна (Ашталковска 2009: 7, 121-122).

„Неконтролираните емоции” кои влегуваат во телесните емоции, може да ги доведеме и во врска со Фуковата општествена контрола на сексуалноста (Michel Foucault) и дисциплинирање на нашите тела, а тука на виделина излегува и казната (Фуко 2004). Целосното препуштање на

${ }^{9}$ АИФ м.л. бр. 3889. Инф. А.П. р. 1930, р. во с. Панчарево-Делчевско, снимено во с. Негрево-Пехчевско. Снимла: В. Петреска во с. Негрево во 2001 год.

10 За чесноста/нечесноста на невестата, која имала едно од централните места во свадбената обредност и кај други словенските народи, постои обемна литература, да се види на пр. (Узенӗва 1999: 145-157; Гура 1978: 86-88; Гура 1990: 35; Агапкина 1994: 88,106 и др.). 
телесните емоции, кои ја допреле женската „чесност”, ќе имаат последици за идната жена во понатамошниот брачен живот. Овој „младешки грев" - целосно препуштање на љубовните емоции ${ }^{11}$, се гледа уште во свадбените обреди, по заедничкото сведување на младите, кога било потребно јавно да се објави невестинскиот „белег”. Во овој случај станува збор за нечесна невеста. Објавувањето најчесто било со престанување на музиката, известување на невестините родители со дупната погача, носење на невестата кај стоката да им соопшти дека дошла нечесна, или да ги нахрани пилињата или пак веста се соопштувала на растенијата (Петреска 2002: 497-502). Криењето на нечесна невеста не било дозволено, бидејќи според верувањето, „мора нешто лошо да се случи”, било на луѓето или стоката. Ова верување на терен во најголем број случаи е покриено со кажувања кои ја потврдуваат неговата „вистинитост“ (Петреска 2008: 166). Верувањето јасно покажува дека културата во извесна мера го регулира однесувањето на поединците, на кои им останува правото на избор, дали ќе се однесуваат во согласност со правилата или не, но доколку не се однесуваат, тоа треба јавно да се објави. Вакви обредни активности покрај во македонската традиционална култура, се сретнувале и кај другите јужнословенски култури (Иванова 1984: 131; Đorđević 1968: 160; Frejdenberg 1980; Раденковић 1996: 38-41, 355), кај Русите објавувањето на нечесноста се вршело со откривање покривот на куќата; поставување на покривот расипано тркало (Байбурин 1983: 178).

„Неконтролираните љубовни емоции” ќе имаат тешки последици по девојката во колку нејзиниот брачен живот не завршува со саканиот, т.е. со оној со кого го направила „младешкиот грев”. Во вакви случаи девојката се мажела за вдовец, или пак доколку се омажела за друг, казните биле неизвесни: од нејзино враќање во домот на нејзините родители по недостатокот на „белегот”, физичките казни, но, можеби најтешките казни што жената ги доживува самата во себе се постојаните префрлања од сите во куќата, а особено доколку се случи некој несреќен настан во семејството, а во прв ред со нејзиното потомство според народното толкување е резултат на нејзината нечесност.

${ }^{11}$ Во прилог на ова, може да се спомене дека во некои словенски јазици сексуалниот однос и се именува како да се огрешил. На пр. во рус. грех, согрешить, укр. боже сохрани (Gura 2005: 136), во македонскот ,,ја згрешив/ ја згрешивме”. 
Доволно ќе бидат неколку примери земени од теренските материјали, каде јасно се изразува казната што ја доживува „нечесната жена”, казна која буди емоции на гнев, лутина во прв ред кон самата себе, што не успеала да се „контролира во младоста. Во една приказна „нечесната жена" родила дете со хендикеп. Го оженила детето за некоја сиромашна жена, но и снаата родила деца со хендикеп; „Дека нечесна, наsад тргна куќата” ${ }^{2}$. Во друга приказна „нечесноста” на невестата се одразила на нејзиното потомство, односно на нејзиниот син чија жена умрела на породување ${ }^{13}$. Верувањето дека „неверството” може да се покаже на следното поколение, е еден од современите примери, медиумски претставено ${ }^{14}$. Воопшто жената што се здобила со атрибутот „женски неморал” чие поимање било ограничено на женска физиологија, ќе ја прати и во понатамошниот живот, на што особено ќе ја потсетува мажот: „ти ко девојка не беше за верување не па сега"15. Со ваков атрибут жената можела да се здобие и во понатамошниот живот, за што доволно било средба, посета или разговор со друг маж во отсуство на сопствениот, за да проработи механизмот на озборување. Озборувањето можело да проработи и како резултат на физичкиот изглед на жената. За ваквата состојба потврда наоѓаме во поговорките од типот: „Ако жена ти е многу убава, не ја пуштај сама на свадба”, „Ако имаш лична жена, повеќе пријатели ќе те фатат”, „Ако имаш лична жена со пријателите ќе ја делиш”, „Кучката ако не мрда/не мрдне со опашката, кучињата не трчаат по неа”, „Убавата жена ретко е чесна”

12 АИФ м.л. бр. 3738, инф. В.Ј. р. 1920 г. во с. Царев Двор - Преспа. Снимила: В. Петреска во с. Подмочани - Преспа во 2000 год.

${ }^{13}$ АИФ м.л. бр. 3751, инф. С.И. р. 1927 г. во с. Добровница - Кривопаланечко. Снимила: Ј. Цветановска во с. Добровница во 2000 год.

${ }^{14}$ Српска емисија Porodične tajne која беше емитувана на македонската национална АЛФА ТВ, во 2014. Накратко млад брачен пар добива ќерка, која има црн тен. Мажот ја обвинува жената дека ќерката не е негова. Жената за да ја докаже нејзината правда бара да се направи ДНК анализа на крвта. По извршената анализа се утврдува дека ќерката е негова, а генот со потемен тен медицински се објаснува дека можеби некој од претходните генерации имал некоја афера со лице со таков тен. Мајката на момчето му признава дека таа имала афера, а плод на таа афера е самиот тој. Наместо традициионалното верување кое главно се потпира на натприродното, дека „мора да излезе на виделина”, во овој случај имаме медицински поткрепено верување.

${ }^{15}$ АИФ м.л. бр. 3751, инф. С.И. р. 1927 год. во с. Добровница - Кривопаланечко. Снимила: Ј. Цветановска во с. Добровница во 2000 год. 
(Величковски 2009: 21-22, 109, 209). Во ваква состојба жената тешко можела да го отфрли обвинението. Во еден пример наклеветена жена пред маж за прељуба, успеала да се оправда пред него со бакнување на леб и сол, но, веднаш потоа истиот леб го однела во црква и бакнувајќи го, ги проколнала клеветниците. Случувањето на некоја несреќа на секој од клеветниците било доволен доказ за жената, но и за мажот дека таа била наклеветена (Цветановска 2012: 215-216).

Врз основа на претходно изнесеното она што можеме да резимираме е дека љубовта и љубовните емоции биле во согласност со општествените и културните критериуми на заедницата во кои настануваат. Ова значи дека во голем дел нивното изразување било во согласност со организацијата на општествениот живот во традиционалната култура со двата доминантни принципа пол и возраст, како и со вредностите што ги пропишала традиционалната култура - животот и честа. Во соглсност со ова идеалниот модел подразбирал криење на љубовните чувства на младите и изборот на брачниот другар да биде по желба на родителите. Но, покрај идеалниот модел, во реалниот живот многу често се случувало да постојат љубовни емоции меѓу младите, за што примери беа стапување во брак на младите по нивна желба која не е во спротивност со онаа на родителите, и бегалките. Но, во најголем број случаи љубовните емоции морале да се контролираат, или пак да се покажат онолку колку што било дозволено во традиционалната култура. Станува збор дека љубовните емоции биле во сферата на духовното, додека телесните емоции особено девојката морала вешто да ги прикрива или да ги покаже во најмала мера. Во спротивен случај настапува и казната.

Овде ја допираме честа, која кога се во игра љубовните емоции, таа во прв ред се однесува на честа на жената, под која во традициските култури се подразбира женската сексуална чесност и невиноста на девојката. Мажот не подлежи на казни поради љубовни сексуални емоции, селската заедница може да не го одобрува неговото однесување, но подлабоки последици нема. Теренските материјали од различни предели на Македонија, но, и во поширок балкански контекст покажуваат дека доколку се прекрши ова правило, се сметало дека тоа е еднакво како да се показила „честа” на мажот, а со тоа и на целата негова фамилија. Многу автори сметаат дека просторите на Медитеранот и Балканот ставаа голем нагласок на чесноста и невиноста 
на жената. Одбраната на женската чесност се изедначува со „честа” (Herzfeld 1980: 339; Đordano 2001: 125-126). Примери за ова можеме да најдеме и во канонот на Лек Дукаѓини (Гечови 1994: 57, 137-138, 180-181, 184). „Нечесноста на жената” покрај што го имало значењето на осрамотување на мажот и целата негова фамилија, исто така многу повеќе значело и посрамување на семејството на девојката, особено нејзиниот татко бидејќи не успеал да ја контролира сексуалноста на својата ќерка. Неуспевањето да се контролира „женската сексуалност" доведува до казна која ги погодува двете семејства, но, особено со тоа е засегната девојката, казна која ја прогонува во текот на животот, за нејзините „неконтролрани” телесни уживања. Извесно задоволување на правдата на изневерена девојка која целосно се препуштила на љубовните емоции или на неправедно обвинета жена за неверство е посегањето кон клетвата, и случувањето на некоја несреќа на оние кон кои е упатена клетвата.

Но, мора да имаме на ум дека и во традиционалната култура има отстапување од ваквото поимање на женската чест, каде на целосното препуштање на љубовните страсти не се гледало строго. Како такви би можеле да ги споменеме примерите кога неконтролирните љубовни емоции завршуваат со брак; не се ретки примерите во кои на „неконтролираните предбрачни љубовни емоции" невестата ја потсетуваат краток период, за во понатамошниот живот воопшто и да не се споменува; кога се работи за сиромашни момчиња или пак кога се работи за пасивни краишта, во кои многу девојки не сакале да доаѓаат во колку биле од поплодни краишта (Петреска 2013: 41). Затоа можеме да се сложиме со истражувачите кои сметаат дека поимот на „чест”, во медитеранските и балканските простори долго време бил разгледуван од странските истражувачи егоцентрично, не земајќи ги во обзир и локалните гледања на населението, каде секој член на заедницата се однесува во согласност со јавното вреднување на овој поим (Herzfeld 1980: 342-343).

\section{Литература}

Агапкина А.Т., 1994, Южнославянские поверья и обряды, связанные с плодовыми деревьями, в общеславянской перспективе, во: Славянский и балканский фольклор. Верования, текст, ритуал, Москва, стр. 84-111. 
Ашталковска А., 2009, Озборувањето како механизам за соичјална контрола во народната култура на Струшки Дримкол, Скопје.

Байбурин К.А., 1983, Жилище в обрядах и представлениях Восточных Славян, Ленинград.

Величковски Б., 1989, Македонски еротски народни песни/ Секој петок урда јадаам, Охрид.

Величковски Б., 2009, Македонски пословици и поговорки, Скопје.

Гура В.А., 1978, Опыт выявления структуры севернорусского свадебного обряа (по материалом Волгорской грб.), во: Руский народный свадебный обряд, уред. К.В. Кистова, Т.А. Бернштам, Ленинград, стр. 72-88.

Гура В.А., 1990, Пъвата брачна нощ в славянския сватбен обред, „Български фолклор" кн. 1, София, стр. 29-41.

Ѓечови А.К.Ш., 1994, Канонот на Лек Дукаѓини, прев. К. Мехмети, Тетово.

Иванова Р., 1984, Българската фолклорна сватба, София.

Икономов В., 1988, Старонародни песни и обичаи од Западна Македонија, Скопје.

Кајмаковић Р., Костић П., 1961, Библиографија женидбених обичаја, „Гласник Етнографског музеја” бр. 24, стр. 153-176.

Караџић В.С., 1974, Српске народне пјесме из необјављених рукописа Вука Стеф. Караџића, књ. 5, Особите пјесме и поскочище, прир. Ж. Младеновић, В. Недић, Београд.

Караџић В.С., 1975, Српске народне пјесме, књ. 1, Београд.

Малинов 3., 2006, Традииионалниот народен календар во Шопско-Брегалничката етнографска иелина, Скопје.

Мартиноска А., 2007, Голиот на гости. Антологија на македонскиот еротски фолклор, Скопје.

Миладиновци Д. К., 1962, Миладиновци. Зборник 1861-1961, Скопје.

Пенушлиски К., 1974, Кон проучувағето на македонските еротски песни, „Македонски фолклор” бр. 14, стр. 67-85.

Пенушлиски К., 1989, Македонски еротски приказни, Скопје.

Петреска В., 2002, Свадбата као обред на премин кај Маедонците од брсјачката етнографска иелина, Скопје.

Петреска В., 2008, Категоричте близина и дистанца: етнолошко-антрополошко истражување во народната култура, Скопје.

Петреска В., 2012, Клетвата во македонската народна култура, „Poznańskie Studia Slawistyczne" nr 3, стр. 129-143.

Петреска В., 2013, Бракот и сродството во Порече во времето на проучувањето на Јозеф Обрембски до денес, во: 105 години од раѓањето на Јозеф Обрембски, уред. Е. Луческа, 3. Димоски, Прилеп-Познањ, стр. 33-46.

Пиличкова С., 2009, Еротски елементи во турското народно творештво од Република Македонија, Скопје.

Попвасилева А., 1996, Македонски народни приказни од Костурско, Скопје.

Раденковић Љ., 1996, Симболика света у народној магији јужних Словена, књ. 67 , Посебна издања, Ниш. 
Ристески М., 1961-1962, Селска свадба I-V, „Стремеж” год. 7-8, Скопје.

Ристески Д.М., 1994, Македонски еротски песни, књ. 1, 2, Скопје.

Ристовски Б., 1975, Машките еротски народни песни околу коледниот огин во некои места во Македонија, „Македонски фолклор” бр. 15-16, стр. 219-228.

Тановић С., 1927, Српски народни обичаи у Ђевђелиској Кази, „Српски етнографски зборник” књ. 14, Београд.

Топорков А.Л., 1995, Русский эротический фольклор, Москва.

Топорков А.Л., 1996, Секс и эротика в русской традиционной културе, Москва.

Узенёва С.Е., 1999, Бъчва без дъно... К символике девственности в болгарском свадебном обряде, во: Д. Ајдачић, Кодови словенских култура, т. 4, Делови тела, Београд, стр. 145-157.

Фуко М., 2004, Надзор и казна. Раѓаъето на затворот, прев. Н. Ѓондева, Скопје. Хаџи-Васиљевић Ј., 1927, Ресен и његова околина, „Братство” бр. 21, стр. 40-55.

Цветановска Ј., 2012, Гревот и казната. Во народната култура на Македонците, Скопје.

Целакоски Н., 1984, Дебариа. Обреди, магии и магиски песни, Скопје.

Шапкарев К., 1976, Избрани дела, т. 3, Песни, прир. Т. Саздов, Скопје.

Ajdačić D. (prir.), 2000, Erotsko u folkloru Slovena. Zbornik radova, Beograd.

Aarne A., 1964, The types of the Folktale. A classification and bibliography, „FF Communicatios" no. 184, trans. S. Thompson.

Foucault M., 1978, The History of sexuality, t. 1, New York.

Frejdenberg M.O., 1980, Ulazak u Jerusalim na magarcu. (Iz jevanđeljske mitologije), „Delo” br. 11-12, стр. 1-46.

Freud S., 1988, Nelagodnost u kulturi, Beograd.

Gura V.A., 2005, Coitus in the symbolic language of Slavic Culture, <http://www. folklore.ee/folklore/vol30/gura.pdf >, 11.12.2014.

Đordano K., 2001, Ogledi o interkulturnoj komunikaciji, Beograd.

Đorđević D., 1968, Neki arhaični elementi u običajima prve bračne noći u Leskovačkom kraju, во: Zbornik XII Kongresa jugoslovenskih folkloristov, ur. Z. Kumer, Ljubljana, стр. 159-161.

Herzfeld M., 1980, Honour and Shame: Problems in the comparative Analysis of Moral Systems, „MAN” no. 15, стр. 339-351.

Hoffmann F., 1973, Analytical Survey of Anglo-American Traditional Erotica, Buffalo.

Grzybeg P., 1999, South Slavic Erotic Folklore. Remarks on Tradtional Erotic Phrazeology from Dalmatia, „SB” 1-4, 99, 131-154.

Krstić B., 1984, Indeks motive narodnih pesama Balkanskih Slovena, Beograd.

Thompson S., 1955-1958, Motiv Index of Folk Literature, t. 1-4, Bloomington.

Škokić T., 2011, Ljubavni kod. Ljubav i seksualnost između tradicije i znanosti, Zagreb. 